\title{
Perubahan Paradigma Studi Agama pada Program Studi Perbandingan Agama Universitas Islam Negeri (UIN) Sunan Ampel, Surabaya
}

\author{
Ahmad Zainul Hamdi \\ Universitas Islam Negeri (UIN) Sunan Ampel, Surabaya \\ z.hamdi@uinsby.ac.id
}

\begin{abstract}
This article is aimed to assess the progress of Islamic and religious studies at State Islamic University (UIN) Sunan Ampel Surabaya throughout the view of new paradigm on Islamic studies. It attempts to seek whether there is a shifting paradigm from parochial Islamic studies to dialogical Islamic studies that could accommodate contemporary social scientific instruments. It is based on one core question, "is the Islamic studies at UIN Sunan Ampel-especially the Department of Comparative Study of Religions-still based on normativedoctrinal studies or based on historical critics?" This paper took four undergraduate theses as a sample, starting from 2011 back to forty years before. Each thesis represents one-decade period. In order to analyze religious studies at the Department of Comparative Study of Religions will be a strategic stage to observe methodological perspective, namely insider-outsider perspective. Having examined all of these theses, this article concludes that Islamic religious studies at the Department of Comparative Study of Religions have not changed at all. It shows signs of stagnating after four decade of teaching religious studies in this department.
\end{abstract}

Keywords: Islamic Studies, Sifting Paradigm, Insider-Outsider Perspective. 


\section{Pendahuluan}

Artikel ini hendak menilai perkembangan studi Islam di PTAIN (Perguruan Tinggi Agama Islam Negeri) dari kacamata paradigma baru studi Islam dengan mengambil kasus pada Program Studi Perbandingan Agama Fakultas Ushuluddin dan Filsafat Universitas Islam Negeri (UIN) Sunan Ampel, Surabaya. Bukan tanpa alasan jika artikel ini berjudul "Perubahan paradigma dalam Studi Agama". Istilah ini barangkali adalah istilah yang paling tepat untuk menggambarkan arus baru studi Islam. Istilah ini diperkenalkan sebagai "kata-kata penanda" oleh Carl W. Ernst dan Richard C. Martin dalam melukiskan arah baru studi Islam yang babakan awalnya sudah dimulai oleh Charles J. Adams di tahun 1967. ${ }^{1}$

Artikel ini ingin melihat apakah ada pergeseran paradigma dari kajian keislaman parokial menuju satu studi Islam yang mampu berdialog dengan berbagai perangkat dan temuan keilmuan kontemporer? Apakah kajian keislaman di UIN Sunan Ampel, Surabaya, khususnya di Prodi Perbandingan Agama (selanjutnya disingkat PA), masih terjerat dalam studi-studi normatif-doktrinal atau sudah bergerak dengan memanfaatkan pendekatan historis dan berbagai teori kritis?

Ini adalah pertanyaan mendasar yang hendak dijawab dalam artikel ini. Untuk menjawab pertanyaan tersebut, saya menyurvei skripsi mahasiswa Prodi PA. Ada empat skripsi yang diangkat di sini. Skripsi ini diambil secara acak, di mana per satu skripsi mewakili satu dasawarsa (periode sepuluh tahunan), yang dihitung mundur dari tahun 2011. Jadi, artikel ini berarti melihat dinamika perkembangan studi Islam dalam kurun 40 tahun terakhir.

Skripsi menjadi penting untuk ditelaah karena dia adalah tugas terakhir mahasiswa yang menjadi simbol pencapaian keilmuan yang digelutinya. Skripsi dibimbing langsung oleh dosen sehingga ia juga bisa memperlihatkan arah dan kecenderungan keilmuan dosen. Skripsi

\footnotetext{
${ }^{1}$ Lihat Carl W. Ernst dan Richard C. Martin, "Introduction, toward a Post-Orientalist Approach to Islamic Religious Studies" dalam Retbinking Islamic Studies from Orientalism to Cosmopolitanism, Carl W. Ernst dan Richard C. Martin (ed.), (Columbia: The University of South Carolina Press, 2010), 7.
} 
dipertahankan dalam sebuah majelis akademik di mana beberapa orang dosen-dengan fungsi yang beragam-menguji dan berusaha memperbaiki skripsi agar menjadi suatu karya akademik yang memungkinkan seorang mahasiswa diberi gelar sarjana di bidang keilmuan yang digelutinya. Jadi, melongok skripsi mahasiswa akan memperlihatkan perkembangan dan dinamika keilmuan di sebuah jurusan atau program studi.

Prodi Perbandingan Agama layak untuk dikaji karena sebagian sarjana religious studies menyamakan antara fenomenologi agama, salah satu pendekatan utama dalam religious studies/religionwissenschaft/science of religion dengan perbandingan agama (comparative religion). Dengan melihat dinamika perkembangan religious studies di PA, maka kita bisa melihat seberapa jauh dinamika religious studies dan Islamic studies merembes ke dalam UIN.

Selain itu, jika dibanding dengan jurusan lain, misalnya Tafsir Hadis dan Syariah, Prodi PA adalah jurusan yang paling strategis untuk mengukur dinamika, pengayaan keilmuan Islam, dan berbagai pergeseran paradigma dalam Islamic studies. Hal ini karena perbandingan agama adalah sebuah jurusan yang mengkaji agama tidak dari kacamata normatif, tapi melihatnya sebagai sebuah fenomena manusia (individual dan sosial), di mana berbagai perkembangan ilmu-ilmu sosial-humaniora baru semestinya langsung berpengaruh di sini.

Melihat religious studies pada Prodi PA juga akan menjadi langkah strategis dalam melihat metode kajian agama dari perspektif outsider. Hal ini akan bisa melahirkan pertanyaan krusial dalam studi agama: Apakah sebagai outsider, sarjana PA mengkaji agama orang lain dengan semangat superioritas penundukan atau sebagai complete observer dengan sikap hormat dan empati?

Saya ingin menyatakan bahwa sementara Prodi PA melakukan studi terhadap berbagai keyakinan keagamaan di luar Islam dan memperkayanya dengan berbagai perangkat ilmu-ilmu baru, namun epistema nalar Islam yang berkuasa belum beranjak dari nalar bayânî. 
Nalar bayânî adalah nalar yang tunduk secara normatif pada teks. ${ }^{2}$ Nalar seperti ini menghasilkan kajian keislaman yang semata-mata normatif dan memandang ilmu-ilmu baru dengan kacamata curiga, bahkan bermusuhan. Karena itu, maka selalu ada "irremediable tension between the scholars who exercise doctrinal authority and the specialist in relevant disciplines, such as history, sociology, psychology, linguistics, and semiology."3

Studi terhadap keyakinan agama lain, sebagaimana yang terpotret secara jelas dalam skripsi, hanya sarana untuk semakin meneguhkan sikap superior Islam dan umat Islam atas agama dan umat agama lain. Inilah gambaran studi keagamaan (religious studies) dengan semangat kolonial warisan Orientalisme yang sudah banyak dikritik dan ditinggalkan orang, tapi tetap dijalankan.

\section{Dari Orientalisme ke Post-Orientalist Islamic Studies}

Tradisi akademik kajian Islam di Barat bermula dari Orientalisme. Sebagaimana yang disimbolkan dalam istilah Orientalisme, studi Islam hanyalah salah satu sub kajian wilayah di mana Timur, dengan berbagai kompleksitas dan detail-detail yang ada di dalamnya, menjadi area yang ditatap, dikurung, dan dipelajari. Seakan-akan, segala sesuatu yang ada di Timur memiliki kesatuan dan kesolidan kategori sehingga bisa dimasukkan dalam satu box yang disebut Orientalisme. Orientalisme berkembang pesat pada abad ke-19 dan 20 di Eropa dan Amerika Serikat. ${ }^{4}$

Dengan memanfaatkan pikiran-pikiran Michael Foucault, Edward Said membongkar Eurocentrism yang mengendap di balik aktivitas Orientalisme. ${ }^{5}$ Tidak seperti Albert Hourani yang memberi informasi

\footnotetext{
2 Muhammad 'Âbid al-Jâbirî, Bunyat al-'Aql al-'Arabî: Dirâsab Taḅlilîyah Naqdîyah li Nažm al-Ma'rifah fí al-Thaqâfah al-'Arabiyah (Beirut: al-Markaz al-Thaqafì al-'Arabî, 1993), 75.

${ }^{3}$ Mohammed Arkoun, "Rethinking Islam: Common Questions, Uncommon Answers," ter. Robert D. Lee, dalam Howard M. Federspiel (ed.), An Anthology of Islamic Studies, Vol. 2 (Montreal: McGill Institute of Islamic Studies, 1996), 60.

${ }^{4}$ Carl W Ernst dan Richard C Martin, Retbinking Islamic Studies Frorm Orientalism to Cosmopolitanism (Columbia: The University of South Carolina Press, 2010), 2-3

${ }^{5}$ Edward Said, Orientalism (New York, NY: Pantheon, 1978). 2.
} 
tentang sejarah intelektual Orientalisme Eropa dengan menunjukkan akar-akar tradisi Islamic studies di Eropa dalam masalah ketuhanan, manusia, sejarah, dan masyarakat, Said mengaitkan pembahasannya tentang Orientalisme dengan isu-isu power dan kolonialisme dengan membongkar teks-teks Orientalisme sendiri. ${ }^{6}$

Di sisi lain, di Barat juga berkembang suatu kegiatan akademik yang disebut dengan istilah religious studies. Religious studies awalnya tumbuh di universitas-universitas privat yang memiliki afiliasi dengan agama tertentu (Kristen). Studi agama di level ini dianggap tidak memenuhi standar ilmiah oleh masyarakat akademik. Apa yang disebut dengan religious studies di level ini adalah pengajaran doktrin-doktrin kekristenan yang bersifat normatif dan parokial.

Pasca-Perang Dunia II, ada angin perubahan terkait dengan religious studies. Universitas-universitas publik mulai membuka departemen atau pusat-pusat studi agama. Perubahan ini membawa pada satu tradisi keilmuan baru di mana religious studies tidak hanya terpaku pada biblical studies dan teologi Protestan, tapi mulai melakukan studi terhadap agamaagama lain. Pendekatan normatif yang bersifat apologetis ditinggalkan dan mulai memanfaatkan berbagai metode dan teori baru dalam ilmuilmu sosial-humaniora.

Bisa dikatakan bahwa religious studies berusaha untuk keluar dari perangkap sektarianisme agama untuk mendapat pengakuan status keilmiahannya dari masyarakat akademik. Charles Adams menyebut religious studies di era ini dengan istilah religionwissenschaft, sebuah istilah Jerman yang berarti science of religion. Pengakuan religious studies sebagai bagian dari kegiatan ilmiah dikukuhkan melalui pendekatan sejarah atas agama sebagai pengganti pendekatan normatif-parokial. Religious studies sebagai science of religion (religionwissenschaft) ini terkait erat dengan fenomenologi agama.

Douglas Allen memberikan empat definisi fenomenologi agama sebagaimana yang dipahami oleh para sarjana di bidang studi agama. Pertama, fenomenologi agama adalah sebuah investigasi fenomena atau

${ }^{6}$ Ernst dan Martin, Rethinking Islamic Studies, 3.

${ }^{7}$ Ibid., 4-5. 
objek, fakta, dan kejadian-kejadian keagamaan yang dapat diobservasi (an investigation of the phenomena or observable objects, facts, and events of religion). Kedua, fenomenologi agama adalah studi perbandingan dan klasifikasi berbagai ragam tipe fenomena keagamaan (the comparative study and the classification of different types of religious phenomena). Ketiga, fenomenologi agama adalah sebuah cabang, disiplin, atau metode khusus di dalam studi agama (a specific branch, discipline, or method within Religionswissenschaft or religious studies). Dan keempat, fenomenologi agama adalah studi agama yang dipengaruhi oleh filsafat fenomenologi (is influenced by philosophical phenomenology). ${ }^{8}$

Dari berbagai definisi tersebut, ada dua unsur penting dalam fenomenologi agama, yakni: (1) pengalaman keagamaan sebagai fenomena yang distudi dan (2) filsafat fenomenologi sebagai perspektif yang digunakan dalam aktivitas studi. Fenomenologi agama starts with the view that religion is based on religious experience. ${ }^{9}$ Di samping itu, fenomenologi agama juga utilizing a phenomenological method dalam melihat pengalaman keagamaan yang dikajinya. ${ }^{10}$

Sampai ketika religious studies berkembang menjadi suatu kegiatan ilmiah, kajian Islam tetap belum merupakan bagian dari aktivitas ini. Kajian Islam tetap berada dalam studi kawasan dengan asumsi-asumsi awal yang dipancang oleh para orientalis. Kenyataan ini sangat disadari oleh Adams ketika dia menjadi satu-satunya sarjana yang mempresentasikan paper tentang Islam pada pertemuan tahunan AAR (American Academy of Religion) di tahun 1973. ${ }^{11}$

Adams bisa dianggap sebagai sarjana awal yang mengkritik kemandekan studi Islam dan terisolasinya Islamic studies dari dinamika religious studies. Kritik Adams ini kemudian mendorong kajian Islam masuk ke dalam wilayah religious studies. Pendekatan historis dalam studi Islam dianggap Adams menjadi jalan awal bagi kajian Islam untuk keluar

\footnotetext{
8 Douglas Allen, "Phenomenology of Religion," dalam The Routledge Companion of the Study of Religion, John R. Hinnells (ed.) (London and Ney York: Routledge, 2005), 185.

${ }^{9}$ Ibid., 182.

${ }^{10}$ Ibid., 186.

${ }^{11}$ Charles J. Adams, "Forward," dalam Richard C. Martin (ed.), Approaches to Islam in Religious Studies (Tucson: The University of Arizona Press, 1985), viii-ix.
} 
dari Orientalisme dan bergabung dengan religious studies. Islamic studies mulai mengadopsi teori-teori kritis dan Kosmopolitanisme (Multikulturalisme).

Yang dilakukan oleh Adams, Smith, dkk. adalah membangun jembatan yang memungkinkan generasi-generasi berikutnya menyeberang dari Orientalisme ke Islamic (religious) studies. Islamic studies kemudian masuk ke dalam religious studies, bukan area studies (studi kawasan) sebagaimana era Orientalisme. Islamic studies mulai memanfaatkan metode dan teori baru serta masuk ke isu-isu yang lebih segar, seperti, modernitas, politik, gender, dan sebagainya. Islamic studies memperkaya dirinya dengan berbagai teori dan pendekatan baru: Cultural studies, post-strukturalisme, kritik-dekonstruktif teks, studi-studi feminisme dan gender, wacana Poskolonialisme, dan kritik atas Orientalisme itu sendiri. Inilah Islamic and religious studies yang sedang bergetar dalam kerja-kerja atau karya-karya baru. ${ }^{12}$ Inilah yang disebut dengan "paradigm shift of the new Islamic studies."

Sejak tahun 80-an, berbagai forum digelar untuk membahas tentang penerapan teori dan metodologi ilmu-ilmu humaniora dan sosial untuk diaplikasikan dalam studi-studi keislaman. Para Islamisis bertemu dengan ahli dari Asia, Afrika, Amerika, Eropa, para ahli agama lain serta para sarjana di bidang isu-isu hermeneutika, gender, agama dan konflik, dan lain-lain dengan pendekatan yang beragam. ${ }^{13}$

\section{Islamic Studies dengan Paradigma Baru}

Beberapa pendekatan ilmiah yang menggeser paradigma lama sehingga kajian Islam keluar dari kungkungan Orientalisme menuju ke arah post-orientalist Islamic studis adalah sebagai berikut: Pendekatan historis, teori kritis, antropologi, dan sosiologi. Nama-nama seperti Marshall Hodgson, Talal Asad, Alasdair McIntyre, Charles Taylor, Kwame Anthony Appiah, dan Bruce Lawrence adalah nama-nama beken

\footnotetext{
12 Lihat Richard C. Martin, "Islam and Religious Studies: An Introductory Essay," dalam Richard C. Martin (ed.), Approaches to Islam in Religious Studies (Tucson: The University of Arizona Press, 1985), 12.

${ }^{13}$ Ernst dan Martin, Rethinking Islamic Studies, 6-7.
} 
dalam paradigma baru ini. Mereka adalah para sarjana Islamic studies yang memanfaatkan berbagai teori dan metode baru.

Penting untuk dinyatakan di sini bahwa pergeseran paradigma ini sama sekali tidak menghapus berbagai persyaratan ilmu-ilmu keislaman normatif dalam studi Islam. Bruce Lawrence barangkali adalah contoh terbaik bagaimana paradigm shift ini bekerja. Lawrence dikenal sebagai Islamisis yang piawai dalam memanfaatkan teori dan metode keilmuan kontemporer seperti media studies, ilmu-ilmu sosial dan humaniora, teori kritis, hingga political science. Akan tetapi, pada saat yang sama, dia menyatakan bahwa "the best of post-orientalist scholarship in Islamic studies is based on solid training in the languages, texts, and history of premodern Islam." ${ }^{14}$

The Venture of Islam adalah Islamic studies yang dilakukan oleh Hodgson dengan pendekatan sejarah. Berbagai konsep baru yang diperkenalkan Hodgson telah mendorong banyak sarjana untuk melihat Islam sebagai sebuah entitas yang hidup. Pendekatan historis Hodgson menggeser cara pandang lama para orientalis yang memandang Islam sebagai entitas mati yang tidak pernah tumbuh, yang karakter naturnya sudah ditentukan sekali waktu untuk selama-lamanya pada abad ke-7 M di masyarakat suku, di tanah Hijaz. ${ }^{15}$ Pendekatan Hodgson ini akhirnya mendorong para sarjana memberi perhatian yang lebih analitis pada pertumbuhan pemikiran, wacana, moral, dan interaksi sosial dalam masyarakat Islam.

Pendekatan baru yang lain dalam studi Islam adalah pendekatan teori kritis yang dikembangkan oleh Talal Asad. Menurut Asad, studi Islam yang dilakukan oleh para orientalis bersifat Eropa sentris. Menurutnya, rasionalitas Pencerahan abad ke-18 adalah rahim dari konseptualisasi Barat atas agama. Ketika Barat selesai merasionalisasi dirinya (termasuk agamanya), pandangan Barat kemudian tidak fair ketika berbicara agama Asia, terutama Islam, hanya karena Islam bukan produk Barat modern. Menurut Asad, Islam harus dipahami dengan

\footnotetext{
${ }^{14}$ Ibid., 13.

${ }^{15}$ Said, Orientalism, 8-10.
} 
terminologinya sendiri, bukan melalui kacamata superioritas Barat. ${ }^{16}$ Pandangan Asad ini bisa dilacak ke Said dan kemudian ke Foucault.

Pandangan kritis juga ditemukan pada McIntyre dan Taylor. McIntyre dan Taylor bersepakat bahwa modernitas dengan alasan rasionalitas tidak punya hak untuk menyingkirkan tradisi keagamaan. Dari sini, Taylor kemudian beranjak lebih jauh dengan mengintroduksi satu konsep yang sangat kuat: Multikulturalisme. Barat modern harus berhubungan dengan budaya dan tradisi pemikiran di luar dirinya. Kehidupan saat ini seharusnya tidak boleh ada satu budaya yang mengisolasi diri dan tidak memberi pengakuan dan respek kepada pihak lain. Menurut Taylor, multikulturalisme adalah sebuah politics of recognition terutama pada kelompok minoritas atau subultern groups, dalam hal agama, gender, etnis, seksualitas, nasionalisme, dan ras. ${ }^{17}$ Sementara itu, Appiah menekankan pada analisis power dalam membincang multikulturalisme.

Sampai di sini, kita juga perlu mempertimbangkan gagasan Kim Knott tentang outsider yang melakukan studi agama. Kim Knott memperkenalkan istilah complete observer. Dengan memanfaatkan metode etnografi yang akrab dalam disiplin antropologi, Knott menyatakan bahwa studi agama bisa dilakukan oleh outsider. Yang diperlukan adalah reflektivitas. Di sini, seorang intelektual dituntut untuk sadar tentang watak dialogis dari sebuah studi. Perspektif etik (outsider) dan emik (insider) bertemu, berdialog dan melahirkan momentum reflektif. Seorang sarjana perlu tinggal bersama, berpartisipasi dalam kehidupan komunitas dan hidup dengan simbol dan aturan main komunitas tersebut agar bisa memahami struktur budaya (agama) dan makna yang dipegang oleh komunitas itu. ${ }^{18}$ Studi seperti ini hanya mungkin jika sejak awal seorang sarjana memiliki pengakuan (recognition) dan hormat (respect) terhadap komunitas keagamaan yang ditelitinya.

Tawaran ini membawa kita untuk mempertimbangkan ulang keterbatasan konsep-konsep yang selama ini menjadi perdebatan dalam

\footnotetext{
${ }^{16}$ Ernst dan Martin, 9.

${ }^{17}$ Ibid., 10.

18 Kim Knott, "Insider/Outsider Perspectives," dalam John R. Hinnells (ed.), The Routledge Companion of the Study of Religion (London and New York: Routledge, 2005), 246-247.
} 
setiap kerja-kerja ilmiah. Perdebatan tidak lagi berkutat tentang objektif atau subjektif. Sebagaimana yang dinyatakan sendiri oleh Kim Knott, "we find ourselves considering the nature and limits of objectivity and subjectivity, 'emic' and 'etic' positions, 'experience-near' and 'experience-distant' concepts, empathy and critical analysis, the effect of personal standpoint, and the process of reflexivity". ${ }^{19}$

\section{Membaca Skripsi Mahasiswa Perbandingan Agama}

Sebagaimana yang dinyatakan di atas, ada empat skripsi yang dikaji di sini. Skripsi pertama bertahun 1983, yang bisa dianggap mewakili kecenderungan religious studies era '80-an yang berkembang di Prodi PA. Skripsi yang ditulis oleh M. Natsir Abdullah ini berjudul Perkembangan Hindu Dharma di Lombok. Skripsi ini berbicara tentang sejarah perkembangan Hindu Dharma di Pulau lombok yang masuk berbarengan dengan penaklukan Lombok oleh Raja Krisna Kapasika dari Karangasem Bali pada tahun 1740. Skripsi ini juga mengulas ajaran-ajaran dasar agama Hindu. ${ }^{20}$

Yang menarik dari Skripsi ini bukan berada pada kesimpulannya, tapi justru pada saran dan motonya. Saran dan moto ini mengindikasikan sangat jelas untuk apa studi ini dilakukan. Dalam sarannya tertulis, "kepada seluruh umat Islam dituntut untuk waspada terhadap pahampaham yang pada hakikatnya bertentangan dengan Aqidah Islamiyah, terutama sekali paham Hinduisme yang masih mengakar di kalangan umat Islam." Sementara, dalam moto yang tertulis di bagian awal, penulis mengutip surah Ali Imran: 85, yang artinya, "Barang siapa mencari agama selain agama Islam, maka sekali-kali tidak akan diterima (agama itu) dari padanya, dan dia di akhirat termasuk orang-orang yang rugi."

Skripsi kedua adalah skripsi yang ditulis oleh Agus Chamim dengan judul Teori Evolusi Agama dalam Hubungannya dengan Asal-Usul Agama (Suatu Tinjanan Theologis). Skripsi ini bertahun 1989/1990 yang bisa

\footnotetext{
19 Ibid., 243.

${ }_{20}$ M. Natsir Abdullah, "Perkembangan Hindu Dharma di Lombok" (Skripsi-IAIN Sunan Ampel Surabaya, 1983).
} 
kita perlakukan sebagai kecenderungan religious studies di Prodi PA era 1990-an. ${ }^{21}$

Sebagaimana yang terindikasi dalam judul, skripsi ini memfokuskan pembahasan pada berbagai teori yang membahasa perkembangan agama. Dalam analisisnya, skripsi ini menyatakan bahwa agama berkembang mengikuti usia peradaban manusia: Bayi, anak-anak, dan remaja. Masa bayi adalah agama yang dipeluk sejak Nabi Adam hingga Nuh. Perkembangan berikutnya, masa kanak-kanak sampai remaja, adalah agama-agama yang dibawa oleh nabi-nabi Israil. Sedang, tingkat terakhir adalah Islam, di mana tauhid diajarkan secara sempurna, tauhid yang tidak bisa menerima apa pun jenis syirik.

Karena Islam adalah manifestasi kesempurnaan dari perkembangan agama, maka agama ini diserukan kepada seluruh umat manusia. Agama ini memiliki ajaran lengkap. Islam tidak hanya berisi ajaran ketuhanan dan peribadatan, tapi juga berbagai aturan-aturan hidup, misalnya, politik, ekonomi, wasiat, perdamaian, dan lain-lain.

Menurut skripsi ini, agama tidak bisa ditinjau dari sudut pandang sosiologi karena itu akan terjebak pada pengakuan bahwa agama itu produk pemikiran manusia. Di antara dua teori perkembangan agama (dari politeisme ke monoteisme dan dari monoteisme yang kemudian diselewengkan menjadi politeisme), skripsi ini memilih untuk bergabung pada teori kedua. Pilihan ini dikuatkan dengan keyakinan bahwa sejak awal agama yang diwahyukan Tuhan kepada manusia pertama (Adam) adalah monoteisme.

Dengan menggunakan argumentasi Alquran bahwa semua manusia diciptakan dari Adam, maka kesimpulan berikutnya dengan mudah dibuat, bahwa tauhid dalam Islam adalah dasar semua agama. Skripsi ini ditutup dengan tulisan bahwa "...dari berbagai monoteisme Islamlah yang paling murni dan konsekuen sebagai wahyu Tuhan dan yang patut dipercaya."

${ }^{21}$ Agus Chamim, "Teori Evolusi Agama dalam Hubungannya dengan Asal-Usul Agama (Suatu Tinjauan Theologis)” (Skripsi-IAIN Sunan Ampel Surabaya, 1989), 57. 
Skripsi berikutnya adalah Studi Tentang Upacara Adat di makam Mbah Aryo bebangah desa Bangah Kec. Gedangan Kab. Sidoarjo (Ditinjau dari Segi Sosiologis), karya Tutik Maria Ulfa. Skripsi ini bertahun 2001 sehingga bisa dianggap sebagai perwakilan religious studies era 2000-an. ${ }^{22}$

Skripsi ini hendak mengungkap faktor-faktor yang melatarbelakangi serta tata cara upacara adat di makam Mbah Aryo Bebangah di Desa Bangah, Sidoarjo. Melihat judulnya, sangat beralasan bagi pembaca untuk berharap disuguhi sebuah kajian antropologi dengan teknik etnografis terhadap satu praktik ritual yang dilakukan oleh komunitas tertentu. Sebagaimana suatu penelitian etnografis, skripsi ini diharapkan mampu membuka praktik dan makna suatu tindakan ritual dari perspektif pelaku (emik). Tapi, yang ada dalam skripsi ini adalah melihat praktik ritual tersebut dan mengadilinya dari sudut pandang keyakinan peneliti (Islam).

Secara tegas, dinyatakan dalam kesimpulannya bahwa, “...pelaksanaan upacara adat di makam Mbah Aryo Bebangah bila ditinjau dari segi sosiologi agama ada penyimpangan terhadap akidah Islam, dimana pelaksanaan upacara adat di makam Mbah Aryo Bebangah termasuk dalam kategori syirik yang tersembunyi yang tidak terlihat oleh kebanyakan manusia, yaitu meminta pertolongan dari mereka untuk dikabulkan kehendaknya, meminta disembuhkan dari penyakit dan jauh dari bala', dimana perbuatan itu seharusnya hanya patut ditujukan kepada Allah Swt. Hal tersebut menurut ajaran agama Islam termasuk dalam kategori syirik. Syirik merupakan dosa yang amat besar".

Melengkapi kesimpulan ini, saya kemudian menyarankan, "Kepada segenap masyarakat Islam Desa Bangah hendaklah dalam memahami ajaran Islam itu dengan baik dan benar, dan hendaknya berhati-hati dan waspada terhadap perbuatan syirik. Syirik merupakan dosa yang amat besar dan Allah mengharamkan surga bagi orang yang berbuat syirik dan tempatnya ada di dalam neraka."

22 Tutik Maria Ulfa, "Studi tentang Upacara Adat di Makam Mbah Aryo Bebangah Desa Bangah Kec. Gedangan Kab. Sidoarjo (Ditinjau dari Segi Sosiologis)" (Skripsi-IAIN Sunan Ampel Surabaya, 2001), 23. 
Skripsi terakhir bertahun 2010/2011 yang berarti mewakili kecenderungan religious studies terkini (era 2010-an). Skripsi yang berjudul Keberadaan Dukun Terbadap Budaya Masyarakat Suku Tengger di Kecamatan Tosari ini ditulis oleh Mukhtar Nashir. Skripsi ini beranjak dari tiga rumusan masalah: Syarat-syarat seseorang menjadi dukun; Peran dukun dalam Suku Tengger; dan unsur-unsur yang membentuk tradisi keagamaan masyarakat Tengger, terutama Upacara Kasada. ${ }^{23}$

Setelah memaparkan apa saja yang menjadi syarat seseorang untuk bisa menjadi seorang dukun Tengger dan seluk-beluk upacara keagamaan Suku Tengger serta menjelaskan berbagai unsur yang membentuk tradisi keagamaan suku Tengger, ${ }^{24}$ penulis kemudian berubah menjadi pengadil atas keyakinan Tengger dari sudut keimanan penulis: “... penulis sebagai orang yang beragama Islam, menyatakan bahwa ritual-ritual yang dilakukan oleh masyarakat Suku Tengger adalah syirik. Dan Islam sebagai ajaran tauhid yang tidak membenarkan adanya kegiatan dalam bentuk apa pun yang menimbulkan kesirikan. Karena syirik adalah salah satu dosa yang paling besar dan tidak dapat diampuni oleh Allah.”

Penulis kemudian mengutip Surah al-Naîm: 19-23 yang menjelaskan tentang penyembahan berhala secara turun-temurun dari satu generasi ke generasi berikutnya. Untuk semakin menekankan kesirikan praktik ritual tengger, penulis memaparkan,

\footnotetext{
${ }^{23}$ Mukhtar Nashir, "Keberadaan Dukun Terhadap Budaya Masyarakat Suku Tengger di Kecamatan Tosari," (Skripsi-IAIN Sunan Ampel Surabaya, 2010), 67.

24 Kearifan suku Tengger dalam hal kebaikan kepada sesama manusia tidak bisa diapresiasi oleh penulis sebagai kearifan yang bisa muncul dari rahim agama manusia primitif suku Tengger, kecuali harus diasalkan pada sesuatu yang diyakini penulis sebagai keyakinan luhur, yaitu agama Islam. Oleh karena itu, maka ketika di dalam mantra ritual Mulunen ditemukan perintah untuk saling menolong, penulis mengasalkannya pada ajaran Sunan Drajat: Menehono teken marang wong wuto, menehono mangan marang wong kang luwe, menehono busono marang wong kang mudo; menehono ngiyup marang wong kang kudanan (berikan tongkat pada orang buta; berilah makan pada orang lapar; berilah pakaian pada orang yang telanjang; berilah tempat singgah pada orang yang kehujanan). Jika cara penyimpulan seperti ini digunakan, maka seluruh ajaran kebaikan kepada manusia yang ada di semua agama bisa diasalkan kepada Islam karena memang secara umum agama juga menyeru kebaikan kepada sesama manusia.
} 
"Jadi, beriman kepada Allah itu sangatlah penting. Sebab Allah adalah yang menciptakan semua alam sejagat raya ini, termasuk manusia. Bukan Sang Hyang Widhi Wasa menurut ajaran orang Tengger dan apabila mereka masih tetap menyembah selain Allah, maka sesatlah mereka dan gelar musyriklah yang mereka dapat selamanya di dalam neraka. Untuk menghindari sebab-sebab kemusyrikan, maka sebagai seorang Muslim kita harus waspada terhadap adanya kebudayaan yang kadang-kadang sudah merusak keyakinan kita, sehingga banyak yang terjerumus ke jalan yang salah.”

Nada yang sama kembali diulangi dalam saran.

\section{Penutup}

Sebelumnya, mari kita melihat kembali kritik terhadap Orientalisme dalam mengkaji Islam. Asad, dengan memanfaatkan krititisme Said dan konsep-konsep Foucault, melihat bahwa Orientalisme adalah Eurocsentrism. Eropa (Barat) dengan kekuatan rasionalnya memandang Timur dalam sebuah relasi kuasa yang tidak seimbang. Timur dijadikan objek di depan tatapan Barat yang superior. Islam dipandang sebagai agama anak-anak yang jika ingin tumbuh dewasa, maka ia harus menapaktilasi perkembangan Barat sampai ke tahap kedewasaannya saat ini.

Inilah kritik atas Orientalisme yang kemudian membuat para pengkaji Islam dari Barat sebagai outsider meninggalkannya. Di mata para sarjana baru, Orientalisme menyimpan semangat kolonialisme Barat atas Timur. Islam dijelaskan dengan kategori-kategori Barat yang dipaksakan. Islam diadili menurut kacamata Barat. Barat menguasai Timur. Timur Islam menjadi objek yang diam, yang dibedah melalui kacamata Barat, untuk kemudian dikurung dan dikuasai.

Yang dibutuhkan saat ini adalah sebuah Islamic studies yang diperkaya dengan metode dan temuan baru. Di satu sisi, kajian Islam tidak lagi semata-mata dilakukan dari sisi normatifnya, namun juga melalui pendekatan historis yang dipertajam dengan teori-teori kritis. Di sisi lain, relasi outsider dalam mengkaji sebuah agama, termasuk Islam, 
bukan lagi relasi subjek-objek, tapi subjek-subjek (intersubjektivitas). Standpoint seorang outsider perlu didialogkan dengan insider melalui proses studi terlibat (complete observer) yang dibekali oleh sikap empati dan hormat. Sebagaimana yang dinyatakan sangat jelas oleh Fazlur Rahman bahwa, "the investigating subject not be inimical to or prejudiced against the object of his or her study, in this case Islam, but rather be open-minded and, if possible, empathically attuned". 25

Apa yang kita lihat pada karya akademik (skripsi) para mahasiswa Prodi PA sejak empat dasawarsa yang lalu adalah kebalikan dari dinamika Islamic and religious studies di luar sana. Kajian Islam di Prodi PA sama sekali tidak bergerak dari kajian Islam normatif-parokial. Apa yang digagas oleh Adams, Asad, hingga Lawrence sama sekali tidak merembes dalam dinamika kajian Islam di Prodi PA. Islam semata-mata dipahami sebagai doktrin-doktrin beku yang sama sekali tidak bersentuhan dengan realitas. Kajian Islam di Prodi PA tidak sungguh-sungguh mampu memperkaya dirinya dengan berbagai metode dan teori baru yang memungkinkannya untuk bertransformasi dari Ulûm al-Dîn (Islam normatif) ke Dirâsah Islâmîyah (Islamic Studies).

Seperti keangkuhan Barat dalam memandang Timur yang direpresentasikan secara sempurna dalam Orientalisme, Islam normatif dalam memandang agama dan umat agama lain dipenuhi dengan sikap angkuh. Jika ia dibenturkan dengan realitas, Islam normatif akan segera berubah menjadi lisan yang berdakwah. Relasi dengan others selalu dibangun di atas skema we-other, subjek-objek, superior-inferior. Umat dan agama lain dianggap sebagai kanak-kanak yang harus ditolong untuk menuju kedewasaan yang sempurna, yang itu berarti ber-Islam. Islam dihadirkan sebagai kekuatan superior atas yang lain sehingga berhak untuk mengadili pihak lain berdasarkan kategori-kategorinya. Apa yang ditawarkan Kim Knott hingga Fazlur Rahman sama sekali tidak mendengung dalam religious studies di Prodi PA.

25 Fazlur Rahman, "Approaches to Islam in Religious Studies: Review Essay," dalam Richard C. Martin (ed.), Approaches to Islam in Religious Studies (Tucson: The University of Arizona Press, 1985), 192. 
Studi terhadap keyakinan agama lain, sebagaimana yang terpotret secara jelas dalam skripsi, hanya sarana untuk semakin meneguhkan sikap superior Islam dan umat Islam atas agama dan umat agama lain. Superioritas Islam diteguhkan dengan sempurna sambil merendahkan agama lain. Sikap superior serta tidak adanya sikap hormat dan empatik dalam mempelajari keyakinan keagamaan orang lain adalah warisan orientalis yang sudah banyak dikritik dan ditinggalkan bahkan oleh orang Barat sendiri, tapi tetap dijalankan di lembaga-lembaga pendidikan Islam.

Memang getir, tapi tetap harus diakui bahwa tidak ada pergeseran paradigma dalam Islamic and religious studies di IAIN. Kajian Islam di IAIN tidak beranjak dari kajian normatif atas Islam (Ulûm al-Dîn) tanpa memanfaatkan pendekatan dan teori-teori baru yang memungkinkannya untuk bertransformasi menjadi Islamic Studies (Dirâsah Islâmîyah) yang akademik dan saintifik.

\section{Daftar Pustaka}

Abdullah, M. Natsir. "Perkembangan Hindu Dharma di Lombok", Skripsi-IAIN Sunan Ampel Surabaya, 1983.

Jâbirî (al), Muhammad 'Âbid. Bunyat al-'Aql al-'Arabî: Dirâsah Taḅlilîyah Naqdîyah li Nažm al-Ma'rifah fì al-Thaqâfah al-'Arabîyah. Beirut: alMarkaz al-Thaqafì al-'Arabî, 1993.

Chamim, Agus. "Teori Evolusi Agama dalam Hubungannya dengan Asal-Usul Agama (Suatu Tinjauan Theologis", Skripsi-IAIN Sunan Ampel Surabaya, 1989.

Ernst, Carl W. dan Martin, Richard C. Rethinking Islamic Studies Frorm Orientalism to Cosmopolitanism. Columbia: The University of South Carolina Press, 2010.

Federspiel, Howard M. (ed.). An Anthology of Islamic Studies, vol. II. Montreal: McGill Institute of Islamic Studies, 1996.

Hinnells, John R. (ed.). The Routledge Companion of the Study of Religion. London and New York: Routledge, 2005. 
Martin, Richard C. (ed.). Approaches to Islam in Religious Studies. Tucson: The University of Arizona Press, 1985.

Nashir, Mukhtar. "Keberadaan Dukun Terhadap Budaya Masyarakat Suku Tengger di Kecamatan Tosari", Skripsi-IAIN Sunan Ampel Surabaya, 2010.

Said, Edward. Orientalism. New York: Pantheon, 1978.

Ulfa, Tutik Maria. "Studi Tentang Upacara Adat di makam Mbah Aryo bebangah desa Bangah Kec. Gedangan Kab. Sidoarjo (Ditinjau dari Segi sosiologis)", Skripsi-IAIN Sunan Ampel Surabaya, 2001. 